\title{
OPEN AND DISTANCE LEARNING: CULTURAL PRACTICES IN NEPAL
}

\author{
Shesha Kanta Pangeni [sheshakanta@kusoed.edu.np], Kathmandu University School of Education, Nepal
}

\begin{abstract}
Nepali education culture is dominated by face-to-face tutoring. It has a long history starting from the Gurukul culture to the present formal schooling. Emerging practices of using technology in education have been promoting online learning as a form of distance education and gaining popularity. This paper focuses on digging out the contextual reality of open and distance learning (ODL) practices in Nepal beginning with an analysis and the author's personal impression of the context. Core focus is placed to explore and discuss different thematic issues such as modes of learning associated education culture/tradition, flexible learning for Nepali students, ODL as a pedagogical tool for teacher education and implementation of ODL in Nepal. The author's personal reflection, literature review, and insights from learning theories are meaningful to enrich the discourse. The paper concludes showing the promising future of ODL in Nepal as an option to traditional mode of education. In addition, attention is drawn on the need of Open University and role of existing universities for the successful implementation of ODL in Nepal to adapt acculturation of online learning by respecting the need of the new generation of learners at the age of Internet culture.
\end{abstract}

\section{Abstract in Nepali}

नेपाली शैक्षिक संस्कृति शिक्षक र विध्यार्थी एकैठाउँ भेला भएर सिक्रे सिकाउने प्रत्यक्ष शिक्षण प्रक्रियामै रुमलिएको छ । यस परम्पराको लामो इतिहास गुरूकूल संस्कृतिदेखि सुरू भएर अहिलेको औपचारिक विद्यालय शिक्षासम्म पनि कायमै छ। अहिले प्रयोगमा आएका नवीनतम अभ्यासलाई हेर्दा, शिक्षामा प्रविधिको प्रयोगले अनलाईन सिकाइलाई खुला तथा दूर शिक्षाको रूपमा प्रश्रय दिएको पाइन्छ र यसले लोकप्रियता पनि हाँसिल गरेको देखिन्छ । यो लेख, नेपालमा खुला तथा दूर सिकाइका अभ्यासहरूको सन्दुर्भ र वास्तविकतालाई खोतल्न, त्यसमाथि लेखकको वैचारिक प्रभावलाई विश्रलेषण गर्न, र खुला तथा दूर सिकाइका विभिन्न विषयगत समस्यालाई छानबिन र छलफल गर्नमा केन्द्रित छ । जस्तै, "शिक्षाको संस्कृति एवं परम्परासँग सम्बन्धित सिकाइ माध्यमहरू", "नेपाली विद्यार्थीहरूका लागि लचिलो सिकाइ", "शिक्षक- शिक्षाको लागि खुला तथा दूर सिकाइ शिक्षाशास्त्रीय साधनको रूपमा" र "नेपालमा खुला तथा दूर सिकाइको प्रयोग"। छलफललाई सान्दर्भिक र अर्थपूर्ण बनाउन विभिन्न लेख तथा रचनाहरूको पुनरावलोकन, सिकाइका सिद्धान्तबाट प्राप्त अन्तर्दृष्टि एवं लेखकका अनुभावात्मक चिन्तनहरूको प्रयोग गरिएको छ। लेखले नेपालमा शिक्षाको परम्परागत माध्यमको विकल्पको रूपमा खुला तथा दूर सिकाइको भविष्य राम्रो देखिन्छ भन्ने निचोड निकालेको छ। साथै नेपालमा खुला तथा दूर सिकाइको सफल प्रयोग गर्न खुला विश्वविधालयको स्थापना गर्नुपर्ने र हाल सज्चालनमा रहेका विश्वविधालयहरुमा समेत दूर सिकाइको अवसरलाई महत्व दिनुपर्नेमा ध्यानाकर्षण गराएको छ । जसले गर्दा इन्टरनेट-संस्कृतिका नयाँ पिढीमाझ अनलाइन सिकाइलाई संस्कृतीकरण गर्न सकियोस् ।

Keywords: open and distance learning, online learning, web 2.0 technology, e-learning, Nepali education culture, flexible learning.

\section{Introduction}

Education culture in Nepal has been dominated by face-to-face tutoring that has a long history starting from the Gurukul culture to the present formal schooling. In the Gurukul system, students used to go to a Guru's Ashram (teacher's home or temple) where, the Guru used to teach spiritual and religious knowledges and life skills. However, emerging practices of using technology in education has been promoting Online Learning (OL) as a form of distance education and, of late, it has been gaining popularity among Nepali students.

$\mathrm{OL}$ is considered one of the several approaches to electronic learning (e-learning). E-learning is a broader concept of learning that includes the use of all electronic means for learning. However, 
OL is specific to the Internet or Intranet mediated learning opportunities. Bejjar and Boujelbene (2014) define e-learning as the "use of ICT, online media and web technologies for learning" (p.5). One of the best definitions of e-learning could be: a term covering a wide set of applications and processes, such as web-based learning, computer-based learning, virtual classrooms, and digital collaboration. It includes the delivery of content via Internet, intranet/extranet, audio- and videotape, satellite broadcast, interactive TV, CD-ROM, and more. (Singh et al., 2003, as cited in Boezerooij, 2006). Thus, in the context of this paper, OL refers to the mediated learning that comes with Web 2.0 integrated platforms and is accessible via the Internet or Intranet.

Web 2.0 technology describes the integrated web platforms that allow different kinds of online interaction and sharing of information or electronic materials (e-materials). "Web 2.0 is a technology with profound potential for inducing change in the higher education sector" (Franklin \& Harmelen, 2007; p.1). Applications used in the platform for the purpose of creating, sharing, communicating and collaborating make it easy for people to create confidential documents and open interactions even if they are at a far distance. Students and teachers who do not have skills of web designing or web publishing can also create and share their academic works to the world or to their own group of learning community (Thomson, 2008). Therefore, use of Web 2.0 technology has been getting popularity in academia. In addition, Web 2.0 integrated learning platforms foster interactivity, collaboration, creation and sharing among learners for quality learning. However, e-learning goes beyond OL because in e-learning, "the mode of course delivery can be entirely electronic (with or without an instructor) or take a more blended approach integrating electronic and classroom delivery to varying extents" (Wagner, Hassanein, \& Head, 2008; p.27). OL enhanced with Web 2.0 tools is articulated as "the evolution of more user-friendly applications and interactive content encapsulated in learning objects, one need not be a coding expert to take advantage of the learning opportunities that are becoming available on the Web" (McGreal \& Elliott, 2008; p.159). McGreal and Elliott (2008) further highlighted that the developing countries also have a bright future towards accessing wealth of knowledge available in the Internet. The declining cost of hardware, software and telecommunication gives a clue that all such access would be affordable to everyone in the world opening the door to ODL across the globe.

Higher education institutions (HEIs) in Nepal have started implementing OL as e-learning mainly to facilitate the traditional on-campus teaching and learning activities. It is believed that elearning provides new opportunities to both the students and the HEIs by creating new and exciting opportunities (Wagner et al., 2008; p.26). Researchers in the field have explored that elearning tools have brought significant changes in the higher education institutions by reforming their student support system and the process of educational delivery. "The development and introduction of a variety of e-Learning tools (from using email to a digital portfolio and a virtual learning environment) has been causing numerous changes in higher education institutions" (Boezerooij, 2006; p.17).

In the past, Nepali teachers and students had no choices more than chalk and talk including blackboard and textbook as teaching materials. These days, they can use all possible teaching materials covering audio, video, animated and simulated objects, software tools, Internet/Web tools, smartboard, electronic pen, and many more as per the need of the lesson they design. However, very few education institutions possess conducive infrastructure to use technology. Anyway, Nepali education culture is on the way to making a grand shift towards adapting innovative technology. Technology enhanced ODL is another opportunity for the Nepali HEIs to reach the students across the country and beyond. Thus, teaching is not limited within boundaries of four walls of a classroom; courses are accessible to every student connected to the Internet from all over the world. 
Stepping on the above background, in this paper, it is too early to expect visible outcome or impact of ODL implementation in HEIs in Nepal because Nepali universities have not yet institutionalized technology integrated practices as their educating culture.

\section{Contextual problem}

Teacher education programs in Nepal have often been criticized for not sufficiently addressing the needs of the diverse country which hosts more than 120 linguistic and cultural groups. Oftentimes, it has been pointed out that teacher education curricula borrow readymade pedagogical models from the developed world without considering their appropriateness in Nepali classroom contexts. This act of borrowing is thought to be disempowering for the Nepali teacher education community on two grounds: first, Nepali civilizations are deficient of their own pedagogical models; and second, community lacks necessary knowledge and skills to address the problems of exclusion, inequity and meaninglessness in teacher education. Likewise, the ideas of online, flexible, distance and ubiquitous learning are often credited to be the origin of the developed world.

Thereby generating the message that they are the panacea for Nepali teacher education community in resolving the problems of exclusion, inequity and meaninglessness in teacher education, not all, but some critical issues are brought into discourse in this paper with some practice based exemplary insights.

\section{Method of the paper}

This paper is developed by reviewing literature in the field of online learning, distance education, educational culture of Nepal, and present provision on flexible learning options for Nepali students. In addition, reflection on the authors' own practice of teaching and learning at the online and distance education centre at Kathmandu University School of Education (KUSOED) for the last five years- has been a great source of information. The author's reflection also covers cultural perspectives of Nepali educational system which the author attended and through which he completed all of his past academic degrees. Analytical approach in the paper is qualitative with the core focus on cultural dimension of education in Nepal: Chalk and Talk to Technological Teaching. Here, technological teaching refers to an integrated teaching with technologies where audio, video, graphic, simulation, animation, multimedia are considered supporting tools of teaching in both online and offline context (Pangeni, 2014). In addition, this paper also analyses the ODL context with respect to some learning theories particularly socio-cultural theory of human learning and networked learning.

\section{Different modes of learning in Nepali cultural traditions}

Nepal is culturally rich as "it is a multiethnic, multilingual, multi-religious and multicultural country. There are 123 languages being spoken in Nepal whereas 125 castes and ethnic groups are residing in a uniquely harmonized Nepalese society" (Central Bureau of Statistics, 2012; p.1). Such a diversity demands multi-cultural education system and different modes of learning fitting to the existing cultural practices.

Looking back into the history of Nepal, education was limited to the Gurukul Ashrams (teacher's home or temple). The Ashrams were religious venue for education led by the Hindu Gurus (teachers). Likewise, Gumba (study centre/school run by community of Buddhist religion) and Madarasa (study centre/school run by community of Muslim religion) also were the centres for education. Until now, in many places, Gumba and Madarasa are in operation and School Sector Reform Plan (SSRP) (2009-2015) focused on recognizing those traditional modes of education and harmonizing them with alternative open learning provisions. However, all those modes of 
education in the past focused on religious studies and spiritual life. One way lecturing, teacher centred pedagogy, student as an obedient follower of teachers and classroom-based education were the basics that shaped the culture of teaching and learning. Regardless of the venues for education, modes were always face-to-face.

College of Education started adult education program through radio in 1958. It is considered to have been the first initiative towards distance education in Nepal. Another important initiative was the launching of radio education teacher training project in 1978 by the Ministry of Education (MoE) with the technical and financial support from USAID. The project started radio broadcasting since 1980 that was focused on enhancing the professional capabilities of inservice primary teachers having qualification under School Leaving Certificate (SLC) (Dixit, 2009). Likewise, as provisioned in National Education Commission 1993, Distance Education Centre (DEC) was established under MoE in 1994. The centre conducted teacher training and education awareness programs through radio broadcasting. After unification of DEC with National Centre for Education Development (NCED) in 2005, professional development training courses for teachers of primary to secondary level, SLC support, and radio program on education information are being conducted (Dahal, 2014). Policy and directives to regulate open education and distance learning in Nepal are Open Education and Distance Learning Policy 2007 and Directives on Distance Education/Open Learning Program 2007 with its third amendment 2014. Formulating policies and other documentation on distance education and open learning programs is supportive to establishing open schools and formalizing distance learning programs.

There are 84 centres of open school throughout the country covering all 75 districts of the nation (Khanal, 2014). Open schools focus on secondary level students who are out of the mainstream formal education due to various reasons. In doing so, self-learning is a major strategy through different means: radio/TV programs, printed materials, and e-learning contents on the Internet. As stated in the policy documents and directives, open schools and distance education programs are also targeted to the busy job holders, residents of geographically remote places, household workers and seekers of learning and earning together.

These days, adaption of technology has supported to cater the educational services through the Internet. Therefore, MoE has implemented distance education program at school level. Students obtain learning resources from the Internet. However, programs are not fully online. Some of the programs focus on radio tutoring with specific purpose, for example: preparation tutorials for SLC examination. Those tutorials are provided via T.V., FM radios and newspapers.

\section{Flexible learning options for Nepali students}

Flexible learning provides valuable advantages to students in competitive higher education to meet the need of diverse range of students. The central focus of flexible learning is to offer choices about when, where and how they learn (Higher Education Academy, 2016). While offering choices, place and mode of delivery are taken care of that empower learners in a number of ways. For example, students get autonomy to choose any suitable option for studies. In addition, students can handle work, study and social life together which enables them to adapt change with the complexities of the $21^{\text {st }}$ century lifestyle. Moreover, "flexible learning is flexible in terms of start and end times, teaching modes, study materials, place, time, assessment" (Casey \& Wilson, 2005, p.11).

Some popular approaches to offer flexible learning are online or distance study. Opportunities of learning from work and employer engagement, part-time study, web-based or blended learning, time driven programs on students' pace, contact session, workshop and seminar are other examples of flexible learning options. In the Nepali context, some of these options are available 
to a limited number of programs of higher studies at two leading universities: Tribhuvan University (TU) and Kathmandu University (KU). TU offers ODL for bachelor and master programs and KU offers ODL for master programs. These ODL programs from both the universities are for teacher education. Students at the secondary level also have distance learning options for SLC. Besides that, some schools, colleges and universities also offer flexibility in time schedule: evening, day or morning class. Students working full time during the day can join morning or evening classes. For the students in the Himalaya regions, there is a provision of Mobile Schools. Such schools shift their location seasonally (winter and summer) as people living in the Himalaya region move their places of residence.

On the other hand, distance education supported by the Internet technology has opened up doors to multiple options of flexible learning. Nepali students connected to the Internet can access worldwide educational opportunities joining Massive Open Online Courses (MOOCs), elearning, online education and many more offered by various universities around the world. As of April first week 2016, country report of ALISON, one of MOOCs providers states that 29,841 learners have been educated from Nepal participating one or more courses. There are 296,031 sessions in Nepal and 750 courses are studied from Nepal. Thus, Nepal is ranked 31 out of 250 countries participating in courses offered by ALISON (ALISON, 2016). This data demonstrates that Nepali learners are accustomed to grab the opportunities of flexible learning options provided by the Internet technology at their doorsteps. It is the proof of new learning culture being developed among Nepali learners. This new culture is also known as the Internet culture of learning where students can create online community (Balula \& Moreira, 2014) for learning. However, low completion rate 6\%-18\% in MOOCs offered by University of London (Grainger, 2013) indicates flexible learning in the form of MOOCs design may not be appropriate in Nepal because traditional culture of education is dominated by on-campus teaching and learning.

The flexibility in MOOCs can attract massive number of students at a single learning platform. For example, the first free online version of MOOCs attracted 2,200 students at the University of Manitoba, Canada but the number of on-campus enrolment was only 27 (Bates, 2015). Likewise, Graninger (2013) reports Coursera catered its service to 5 million students offering over 400 courses from 90 partner universities around the globe by September 2013. Flexibility in learning has been the mission of the MOOCs where students get a number of benefits including choices of University and course(s) of their needs.

Thus, these days all Nepali students connected to the Internet have equal opportunity to choose varieties of formal and non-formation flexible learning. They can pick any course of their choice from the University of their dream that exists anywhere in the world. In addition, Nepali students have limited options to get education with flexible options at domestic institutions. Starting from secondary level to tertiary level that include initiatives of open schools and ODL at HEIs. The limited flexibility of higher studies are being expanded because every year new courses and programs are offered by TU and KU through ODL. On the other hand, since 2012, Open University Infrastructure Development Board has been working to establishing Open University in Nepal. This a positive sign that Nepali students are getting an autonomous Open University in near future for more flexible higher education. 


\section{ODL as a pedagogical tool for teacher education}

In order to understand ODL as a pedagogical tool for teacher education, this section begins with a convincing definition of Moore and Tait (2002):

"it is the fact that all or most of the teaching is conducted by someone removed in space and time from the learner, and that the mission aims to include greater dimensions of openness and flexibility, whether in terms of access, curriculum or other elements of structure." (p.8)

This definition clearly separates ODL from the traditional approach of attending institutions for knowledge in rigid and structured space, time, and curriculum. However, ODL requires more guided self-learning approach because teachers and students are physically separated. Combination of open and distance together make learning more flexible. As a tool, it can facilitate learning in any situation. Especially, in case of training purposes, open and distance learning can cater to a large number of target groups from different locations and timeframe. For example, the HEIs dedicated to teacher education can offer web-based modular training courses for any number of teachers through a single online training platform like in MOOCs.

Pedagogy is "the function or work of teaching; the art or science of teaching, education instructional methods" (Department of Education, Employment and Workplace Relations, 2009; p.5). In this sense, ODL would be an ideal and practical tool for teacher education in Nepal. Historically, ODL had been used as a tool for teacher training in Nepal. Even these days, none other than teacher education programs are offered by the HEIs through the ODL mode. The purpose of first distance education in Nepal was also dedicated to providing training to in-service teachers aiming at qualification upgrade. It was a teacher training program by radio as discussed in the previous section. The practical aspects were the geographical diversity of the country and need of training services to remote places. It was not possible to call all the teachers to training centres. Nor was it possible to carry out training programs to each school. Therefore, ODL was used as the best tool to bridge the need of training services and geographical barrier aiming to train 5000 teachers per year (Holmes, Karmacharya, \& Mayo, 1991). Theoretically, distance education looks for path to interconnected knowledge (Koirala, 2006) and ODL has the capability to serve a large number of target groups at a time. Likewise, the pace of learners and flexibility of learning in ODL programs are good for teacher training because they provide additional skills to professional qualifications. Such additional skills could be attained at any time while being in-service from anywhere.

These days, with the support of technology, tutorials for any kind of teaching/training or education, can be developed in the form of e-text, graphics, animations, simulations, software package, audio, and video or Sharable Content Reference Object Model (SCROM) packages. Those all kinds of tutorials can be distributed through email, Internet or any other kind of sharable devices. In the e-learning context, tutorials may also refer to the learning platforms that allow personal interaction between individual learners and/or a group of learners with a tutor for discussion, resources sharing, activities and assessment. Thus, ODL has become one of the most resourceful tools for teacher education as teacher education itself is training package to be mastered for teaching. In addition to those all kinds of training resources/materials, web-based ODL also provides synchronous communication with tutors to make the learning design more interactive and collaborative.

Through distance education, access to educational opportunities can be increased regardless of geographically challenged groups of learners; flexibility of time and pace and place of study is guaranteed; teaching learning is individualized; students are free to choose their own learning environment; and learners take responsibility for the pace of learning (Poudel, 2006). These 
features also demonstrate the existence of learner centric pedagogy within the framework of ODL. Therefore, in the context of Nepal, ODL could be one of the best pedagogical tools for teacher education. Busy teachers can choose courses for their professional development matching to their own pace and mode for learning when resources are accessible through the Internet or any other electronic means. However, proper accreditation system should be developed to recognize and formalize the self-learning initiatives.

\section{Implementation of ODL programs in Nepal}

ODL is time demanding and Internet technology has a strong support to expand the ODL programs in the form of MOOCs. For example "the University of London International Programs' initial offering of four MOOCs attracted over 210,000 initial registrations, over 90,000 active students in their first week, from over 160 countries and lead to 8,843 Statements of Accomplishment being attained" (Grainger, 2013; p.4). With the support of the Internet facility and availability of MOOCs many students from Nepal are participating in ODL programs offered by different universities around the world. Example in previous section about the number of students participating in ALISON MOOCs and position of Nepal in their ranking shows attraction of Nepali students towards MOOCs.

Likewise, a partner institution of Indira Gandhi National Open University (IGNOU), International Centre for Academics (ICA), College of Distance Education and Online Studies has been offering various degree programs through ODL mode in Nepal since 2002. Out of 3527 students enrolled in 21 different programs at ICA, 1401 students have graduated to the date. The average completion rate is $37.72 \%$. It has been handling 1200 students at present (ICA, 2016). This data demonstrates the demand of ODL is significant. Further, this could also be an evidence that the culture of ODL is being developed in Nepal.

Following the web-based educational technology for ODL, two of the leading universities in Nepal TU and KU have started online learning. At KU, KUSOED has recently revised the modality of the ODL program that was provided since 2011. The revision differentiates online classes from on-campus classes primarily in the ways of students-teacher communication, interaction and instructional delivery. Convenience and flexibility are the most common reasons for online classes (KUSOED, 2015). Likewise, TU has Open and Distance Education Centre (ODEC) that aims at being a lead centre for e-learning in Nepal by providing resourceful elibrary, conducting virtual classes, ensuring access and equity in higher education, providing professional and non-academic courses, training education professionals in e-learning, epedagogy, e-education and e-management, generating research based new knowledge, developing and using economically viable open and distance LMS, and developing national and international relation with ODL providers to promote higher education (Tribhuvan University Open and Distance Education Centre, 2015). Thus, both the universities have similar modality of ODL pedagogy. However, TU has an independent centre which is fully institutionalized and dedicated only to the ODL but KUSOED focuses on dual mode where ODL comes as an integrated part of regular on-campus programs with the flexibility of mode switching for students.

Implementation of ODL would be the best way to expand access to higher education in Nepal considering country's geographical and cultural diversities. Lessons can be learnt from the practice of Open University of Sri Lanka which covers 30\% of the tertiary enrolment in national universities providing education to students from diverse profile, distributed and representing all ethnic communities through its 28 learning centres across the country (Coomaraswamy, 2013). The University provides computer facilities, audio-visual aids, practical sessions, day school/ discussion classes, tutorials/workshops/tutor clinics for student support at the centres. Another example from the South Asian region is Virtual University of Pakistan (VUP) which has been 
able to provide quality higher education establishing 180 outreach campuses across the 95 cities just in nine years of its establishment. VUP also uses modern technology: the Internet, television and e-learning for both instructional delivery and system management (Malik, 2013).

Scalability of ODL programs can address the educational need of students with diverse profile in terms of their level of education, age, sex, culture, language and geographical locations. On the other hand, innovative educational technologies support to offer any number of courses for any number of programs on an asynchronous and self-paced mode of delivery. However, without higher effort from Nepal government at the national level like in Sri Lanka and Pakistan, it would be hard for existing universities to implement massive service of ODL to students with diverse profile. Furthermore, for successful implementation of ODL in Nepal, HEIs need to be careful in addressing the technological and pedagogical challenges as presented in the discussion section below.

\section{Social processes of learning in the ODL context}

Socialization process is important in the ODL context to motivate and engage students in learning. In the socio-cultural theory of human learning, Vygotsky (1978) describes learning as a social process and human intelligence originates in the society or culture. Vygotsky focuses on social interaction for the development of cognition where learning occurs in two levels: social and individual (interpsychological- between people and intrapsychological-inside the learner) (as cited in UNESCO, 2003). As an implication of this theory for the ODL learning context, it is necessary to provide opportunity of social interaction, collaboration, discourse, modelling and scaffolding through learning platforms.

ICT can help to create collaborative learning environment that allows learners' active collaboration, discourse/discussion, problem solving by creating and providing online support system to scaffold students' evolving understanding and cognitive growth (Anderson, 2010). Most of the HEIs around the world have established e-learning portal/ websites as an on-campus or off-campus learning support system. Many of those e-learning or online learning portals have Web 2.0 tools enabled for synchronous or asynchronous discussion through forum post, chat, wikis, blogs, video conferencing and messaging. However, Kear (2010) states that "a videoconference offers higher social presence than a discussion forum because participants can hear each others' voices and see each other" (p.543). Although the degree of realness in social presence vary depending on medium of communication, students get various options for social presence and interaction in order to engage themselves in learning through online learning platforms. In addition, online learning contents are suitable for self-learning at individual pace which provides learning opportunity at the individual level. This is how online learning system may fit with socio-cultural theory of human learning by providing both social and individual level of cognition for learning.

On the other hand, connectivism as a new domain of learning theory has been proposed by Siemens (2006) in addition to the large domain of learning theories: behaviourism, cognitivism and constructivism that already exist. According to Siemens, knowledge resides beyond human mind and that is triggered with the action of browsing and navigating through digital means including web technology and tools. Learning occurs through interaction, sharing, dialoguing, and thinking together in the network of learners. In addition, technology supports in storing and manipulating knowledge through networked communication. At this point, the proposed theoretical framework has been drawing attention of wider discourse. If the theory is established, web-based ODL can be well defined in the future through network learning. 
The above discussed phenomenon also exemplifies that the innovation and technology in education have been supportive to bring about change in the learning culture around the world up to the level of theory. However, there are some issues on social process of learning in a webbased context. Role of student is always greater than other actors in an online context. "In an online course, students seem more likely to 'take off on their own' even when the instructor is highly involved and paying close attention” (Ke \& Chávez, 2013). The author believes that in any mode of study, face-to-face or web-based/online, focuses are to be placed on students' learning rather than on the teachers' teaching. Without teachers' close care and accompanying, it is not possible to focus on students' learning socialization. In addition, peer learning and group work would also empower social processes of learning. Meanwhile, demonstrating online existence/presence for an individual is not hard, "web 2.0 sites are appealing by being simple to use, very intuitive and free, which means that most people can create and manage their online 'existence', individually and as member of a community" (Balula \& Moreira, 2014; p.3). Here, community is symbolic for socialization for a specific purpose; it could be learning or any other. Therefore, online course creators/facilitators may facilitate socialization process of students in the ODL context by providing chances to form learning community within the designed learning platform.

\section{Discussion}

To catch the pace of changing time and learners' demand, Universities are extending their programs to online learning. Open school extension is one of the best examples from Harvard University, USA. Open and Distance Education Center at Tribhuvan University is a good example in Nepal. Both of the Universities use and rely on online learning support system. These two examples, one from extremely developed country and another from a underdeveloped country exemplify that universities around the globe have been adapting new culture in education. That focuses on expansion of education and student support through the creation of online learning environments. Higher education through ODL mode in Nepal has been in discourse for a long time. In addition, Internet technology has brought varieties of options for Nepali students to access higher education. They are able to choose any University around world and to attend courses or academic program of their choice.

Looking at the recent development in Nepali Universities towards integrating ICT and offering ODL programs, TU and KU have started enculturing technology supported distance learning programs for higher education. This is a good sign for the future of ODL in Nepal. Meanwhile, it is equally important to consider technological and pedagogical challenges: competent human resource, quality of education and lower completion rate of students as reported in MOOCs research. In the context of Nepal, major challenges for ODL instructional delivery are: inconsistency in program/policy implementation, lack of electricity and infrastructure, lack of dedicated, cost effective, efficient telecommunication and the Internet services, poor postal system and poor economic situations and its effects on middle level manpower (Subedi, 2014). Therefore, it is very important to pay special attention to these problems and challenges so that upcoming ODL program design and its implementation in Nepal would be more meaningful.

The critical challenge for web-based ODL in Nepal is the lack of electricity supply and the cost of the Internet connectivity. Nepali people are still living in dark because there is blackout up to 16-18 hours per day in dry seasons. As a result, power backup for ODL server system that hosts e-learning platforms cannot function 24 hours. The operation cost goes high to install alternate power backup. However, KU's attempt to avoid this challenge would be an example for other universities in similar situations. KU has outsourced hosting server from USA so that learning platforms are 24/7 standby and accessible to students and teachers at anytime from anywhere. On the other hand, courses offered by KU are accessible via mobile apps too. The use of mobile 
apps for learning platform has supported to lower the cost of data/connectivity. This shows that institutional commitment would be sufficient to overcome many barriers related to teacher training and student support. Learning lessons from the past challenges are always vital in understanding the context and bring new ways of implementing ODL programs in Nepal. Possibly online mode of delivery that could be responsive to handheld mobile devices and low cost data transmission would be an idea to enhance present practices of open and distance education programs from the instructional delivery perspective.

Nonetheless, ODL has been widely used as a tool for teachers' professional development because of its effectiveness in short modular training courses. In addition, it has been popular for professional development because of flexibility and openness. "Open and distance learning is increasingly used in teacher education in developing and industrialized countries" (Robinson \& Latchem, 2005). Therefore, being in a developing country, Nepali can best utilize ODL mode of education for teachers' professional development training and for many other programs.

Possibilities of teaching without textbook, use of students' experiential learning, participatory learning, and use of Internet resources in ODL certainly create student centric learning opportunities and rich learning resources to address the issues of quality and student motivation. Students in ODL can browse Open Education Resources (OER) that are beyond the capacity of a single institution in providing learning resources. Thus, ODL programs best serve the busy working group of people at their doorstep through various means of ICT supported modes: radio, TV, Internet/ online classes, CD ROMs resources, etc.

\section{Author's reflection}

This section presents the reflection of author's professional and personal practice contributing to modernizing ODL in Nepal through web-based delivery of instruction. When the author joined KUSOED in 2010 as a teaching assistant, internal homework of starting a master program through distance learning mode with online support system for content delivery was ongoing. For the content delivery, learning resources, learning activities and assessment, an e-learning platform was designed using the Moodle. The author concentrated on designing part of the elearning platform. While making the platforms, relevancy of teaching and learning resources were taken care of. Academic administration was working on preparing standard self-learning materials hiring subject experts.

After one year, in 2011 July/August KUSOED announced admission offer to 1-year and 2-year master programs with specialization in Educational Management. It was the first higher education program offered through online learning mode in Nepal. Although, there were other practices of ODL in Nepal, the credit of starting online mode ODL goes to KUSOED. As a responsible person for handling student support and e-learning design, the author always focused on student friendly online learning system design to facilitate the admission process, learning activities, communication and end-semester examination. By doing so, the author achieved great professional skills of authoring courses for online learning, ensuring student support through online course platforms, web-based learning environment design, training faculties and staffs in related skills of using the Moodle platform.

Later in 2014, Open University Infrastructure Development Board also started training on webbased course designing for university teachers from both TU and KU. The author contributed as a facilitator in each of the training programs on online course design. Likewise, after establishing ODEC, TU initially focused on program development and staff/faculty training to prepare human resource to handle its ODL system. There as well, the author contributed in some of the faculty training programs. Thus, the author has been contributing to developing modern ODL 
system in Nepal by sharing relevant skills and knowledge, conducting training for preparing future online course authors and developers.

While evaluating the result of 5- years of ODL practices at KUSOED, student enrolment in the starting year 2011 was encouraging (90-100\% of the target/capacity) but later, the enrolment rate decreased to $5-10 \%$ in the year 2014. There were various reasons behind the decreased enrolment. The major reason was that ODL could not be a real distance or open or online. In the name of distance education, students enrolled from very remote districts were compelled to travel to the capital city Kathmandu to attend orientation, contact sessions, thesis supervision and end semester examination. Even during the admission process, they had to come to the city for sending applications, paying fees and attending the entrance tests. Online learning platform alone could not address all those issues.

Again, starting from 2015 August, KUSOED offered four of its master programs - Mathematics Education, English Language Teaching, Leadership and Management and Sustainable Development - through ODL. This time, programs have been offered in dual mode. Students can switch the mode of study (on-campus or at distance) if and when needed. On campus and web-based support has been improved. All regular faculties are equally responsible for both modes of delivery which was not mandatory before. These changes are considered in order to address the past issues of decreased enrolment and high dropout (88\%). In addition, KUSOED has planned to decentralize student support system by establishing satellite or cluster centres and using mobile technology to reach at the doorsteps of learners. In this regards, NORHED project through the Norwegian Agency for Development Cooperation (Norad) financially supports KUSOED to carry out its various activities in education, research and institutional capacity development for ODL.

\section{Conclusion}

The traditional distance education at the HEIs in Nepal was text-based but technology has brought a number of ways to transform the ODL culture. Acculturation of web-based distance learning in Nepali HEIs demonstrates promising future of higher education with options for flexibility and quality to traditional on-campus teaching culture. ODL best fits various groups of Nepali learners: geographically disadvantaged, unreached through traditional campus systems, job holders and people working abroad who still like to upgrade their qualification from home HEIs. Even international students looking for degrees or courses from Nepal can be benefited.

Tapping the possibilities of integrating various interactive learning tools to enhance web-based learning environment and student support system, ODL can foster quality of education. Furthermore, present worldwide trend shows that there is a clear paradigm shift in learning. Millions of learners go for MOOCs to acquire knowledge, skills and qualification in the field of their personal interest. In this context, Nepal government and Nepali HEIs are already late to address the growing educational demand of new generation that wants the culture of learning online. Thus, effort of Nepali HEIs to expand access to higher education with special focus on acculturation of high-tech ODL is urged.

On the other hand, respect to the Internet culture has been an unavoidable part of the modern life to any person or organization. As a result, existence without exposure to the Internet has been hard to individuals and institutions. This situation forces actors in education (planer, developer, providers and receivers) to modify their usual practices and adapt new education culture valuing innovation, diversity and multiculturalism in Nepali education. 


\section{References}

1. ALISON (2016). Free online courses in Nepal. Retrieved April 2, 2016, from https://alison.com/free-online-courses/nepal

2. Anderson, J. (2010). ICT transforming education a regional guide. Bangkok, Thailand: UNESCO.

3. Balula, A., \& Moreira, A. (2014). Evaluation of online higher education: Learning, interaction and technology. New York, NY: Springer.

4. Bates, A. W. T. (2015). Teaching in digital age. Retrieved from https://opentextbc.ca/teachinginadigitalage/

5. Bejjar, M. A., \& Boujelbene, Y. (2014). E-Learning and Web 2.0: A couple of the 21st century advancements in Higher Education. In A. Gard (Ed.), E-learning 2.0 technologies and web applications in higher education (pp. 1-21). Hershey, PA: Information Science Reference (an imprint of IGI Global).

6. Boezerooij, P. (2006). E-learning strategies of higher education institutions. Czech Republic: CHEPS/UT.

7. Casey, J., \& Wilson, P. (2005). A practical guide to providing flexible learning in further and higher education. Scotland: Quality Assurance Agency for Higher Education Scotland.

8. Central Bureau of Statistics (2012). National population and housing census 2011. Kathmandu: Author.

9. Coomaraswamy, U. (2013). Open University of Sri Lanka. In I. Jung, T. M. Wong, \& T. Belawati (Eds.), Quality assurance in distance education and e-learning: Challenges and solutions from Asia (pp. 241-257). New Delhi, India: Sage.

10. Dahal, M. P. (2014). Distance education and open schools in the context of Nepal. Distance Education, 15(15), 56-62.

11. Department of Education, Employment and Workplace Relations (2009). Towards a national quality framework for early childhood education and care: The report of the expert panel on quality early childhood education and care. Melbourne, Australia: Commonwealth of Australia.

12. Dixit, U. (2009). The use of ICT in teacher training: Nepal's experience. Paper presented at the $13^{\text {th }}$ UNESCO-APEID International Conference on Education and World Bank-KERIS High Level Seminar on ICT in Education, Hangzhou, China.

13. Franklin, T., \& Harmelen, M. (2007). Web 2.0 for content for learning and teaching in higher education. Retrieved from http://www.jisc.ac.uk/media/documents/programmes/digitalrepositories/web2-contentlearning-and-teaching.pdf

14. Grainger, B. (2013). Massive open online course (MOOC) report 2013. London, England: University of London International Academy.

15. Higher Education Academy (2016). Flexible learning. Retrieved March 15, 2016, from https://www.heacademy.ac.uk/workstreams-research/themes/flexible-learning

16. Holmes, D. R., Karmacharya, D. M., \& Mayo, J. K. (1991). Teacher training at a distance: A case study of Nepal's radio education teacher training project. Florida, FL: United States Agency for International Development, Bureau for Science and Technology, Office of Education. 
17. International Centre for Academics (2016). International Centre for Academics, College of Distance Education and Online Studies: About us. Retrieved April 4, 2016, from http://www.ica.edu.np/About-Us.php

18. Kathmandu University School of Education (2015). Frequently asked questions. Retrieved September 11, 2015, from http://kusoede.edu.np/mod/page/view.php?id=3055

19. Ke, F., \& Chávez, A. F. (2013). Web-based teaching and learning across culture and age. New York, NY: Springer. doi:10.1007/978-1-4614-0863-5

20. Kear, K. (2010). Social presence in online learning communities. Proceedings of the $7^{\text {th }}$ International Conference on Networked Learning. 541-548. Retrieved from http://www.lancaster.ac.uk/fss/organisations/netlc/past/nlc2010/abstracts/PDFs/Kear.pd f

21. Khanal, K. (2014). Possibilities of e-learning application in professional development of facilitators at open schools. Distance Education, 29-37.

22. Koirala, V. N. (2006). See to distance or looking from distance. Distance Education, 1-4. Bhaktpur, Nepal: National Centre for Educational Development (NCED).

23. Malik, N. A. (2013). Virtual university of Pakistan. In I. Jung, T. M. Wong, \& T. Belawati (Eds.), Quality assurance in distance education and e-learning: Challenges and solutions from Asia (pp. 220-240). New Delhi, India: Sage.

24. McGreal, R., \& Elliott, M. (2008). Technologies of online learning (e-learning). In T. Anderson (Ed.), Theory and practice of online learning (2 $\left.{ }^{\text {nd }} \mathrm{ed}.\right)$ (pp. 143-165). Edmonton, Australia: AU Press, Athabasca University.

25. Moore, M., \& Tait, A. (2002). Open and distance learning trends, policy and strategy considerations. UNESCO, 23(2), 96. Retrieved from http://bit.ly/KWpkNH

26. Pangeni, S. K. (2014). Technological teaching. The Kathmandu Post, 2014, February 29, 4.

27. Poudel, A. (2006). Open learning: A mode of delivering curricula. Distance Education, 106-116. Bhaktpur: National Centre for Educational Development (NCED).

28. Robinson, B., \& Latchem, C. (Eds.). (2005). Teacher education through open and distance learning: World review of distance education and open learning. New York, NY: Taylor \& Francis e-Library. doi:10.4324/9780203018699

29. Siemens, G. (2006). Connectivism: A learning theory for the digital age. International Journal of Instructional Technology and Distance Learning, 2(1), 3-10.

30. Subedi, R. R. (2014). Problems and prospects of open and distance education in Nepal. Distance Education, 15(15), 148-153.

31. Thomson, H. (2008). Wikis, blogs \& web 2.0 technology. Melbourne, Australia: The University of Melbourne. Retrieved from http://www.unimelb.edu.au/copyright

32. Tribhuvan University Open and Distance Education Centre (2015). Introduction. Retrieved August 15, 2015, from http://odectu.edu.np/index.php/introduction/

33. UNESCO (2003, November 27). Vygotsky's sociocultural theory. Retrieved from http://portal.unesco.org/education/en/ev.phpURL_ID=26925\&URL_DO=DO_TOPIC\&URL_SECTION=201.html 
Open and Distance Learning: Cultural Practices in Nepal Shesha Kanta Pangeni

34. Wagner, N., Hassanein, K., \& Head, M. (2008). Who is responsible for e-learning success in higher education? A stakeholders' analysis. Educational Technology \& Society, 11(3), 26-36. 